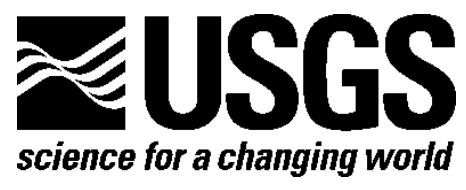

Prepared in cooperation with the Bureau of Land Management and the Great Plains Landscape Conservation Cooperative

\title{
Estimated Historical Distribution of Grassland Communities of the Southern Great Plains
}

By Gordon C. Reese, Daniel J. Manier, Natasha B. Carr, Ramana Callan, Ian I. F. Leinwand, Timothy J. Assal, Lucy Burris, and Drew A. Ignizio

Open-File Report 2016-1184

U.S. Department of the Interior U.S. Geological Survey 


\section{U.S. Department of the Interior \\ SALLY JEWELL, Secretary}

\section{U.S. Geological Survey \\ Suzette M. Kimball, Director}

U.S. Geological Survey, Reston, Virginia: 2016

For more information on the USGS-the Federal source for science about the Earth,

its natural and living resources, natural hazards, and the environment-visit

http://www.usgs.gov/ or call 1-888-ASK-USGS (1-888-275-8747).

For an overview of USGS information products, including maps, imagery, and publications, visit http://store.usgs.gov/.

Any use of trade, firm, or product names is for descriptive purposes only and does not imply endorsement by the U.S. Government.

Although this information product, for the most part, is in the public domain, it also may contain copyrighted materials as noted in the text. Permission to reproduce copyrighted items must be secured from the copyright owner.

Suggested citation:

Reese, G.C., Manier, D.J., Carr, N.B., Callan, Ramana, Leinwand, I.I.F., Assal, T.J., Burris, Lucy, and Ignizio, D.A., 2016, Estimated historical distribution of grassland communities of the Southern Great Plains: U.S. Geological Survey Open-File Report 2016-1184, 13 p., https://doi.org/10.3133/ofr20161184.

ISSN 2331-1258 (online) 


\section{Contents}

Scientific Names for Species Mentioned in This Report .......................................................................iv

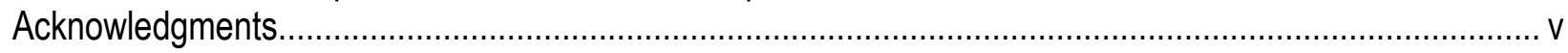

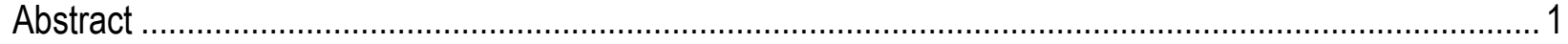

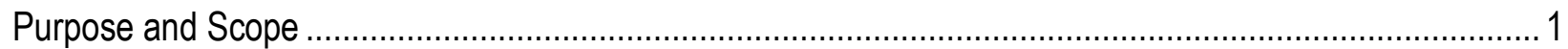

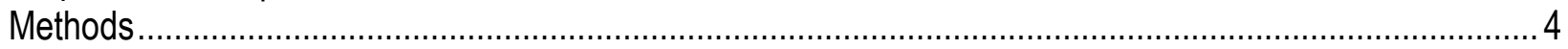

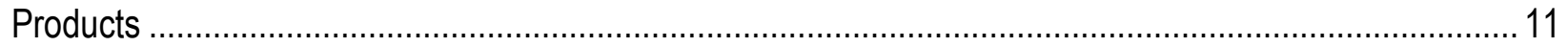

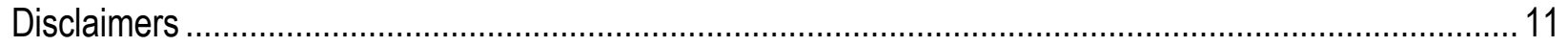

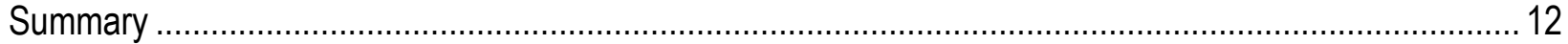

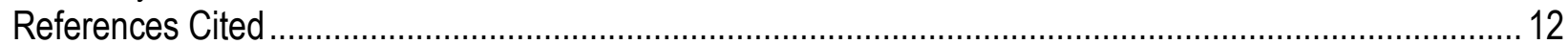

\section{Figures}

1. Map of the Southern Great Plains Rapid Ecoregional Assessment project area ............................ 3

2. Map showing the estimated historical distribution of grassland and adjacent communities in the Southern Great Plains Rapid Ecoregional Assessment project area

\section{Tables}

1. Dominant indicator species used to classify grassland communities ............................................

2. Attributes for the estimated historical grassland communities dataset.......................................... 6

3. Community types for the estimated historical grasslands dataset and corresponding LANDFIRE Biophysical Settings names

\section{Conversion Factors}

U.S. customary units to International System of Units

\begin{tabular}{lcc}
\hline \multicolumn{1}{c}{ Multiply } & By length & To obtain \\
\hline foot (ft) & 0.3048 & meter $(\mathrm{m})$ \\
yard $(\mathrm{yd})$ & 0.9144 & meter $(\mathrm{m})$ \\
\hline
\end{tabular}

\section{Datum}

Vertical coordinate information is referenced to the North American Datum of 1983 (NAD 83).

Horizontal coordinate information is referenced to the North American Datum of 1983 (NAD 83). 


\section{Abbreviations}

$\begin{array}{ll}\text { BLM } & \text { Bureau of Land Management } \\ \text { BpS } & \text { Biophysical Settings } \\ \text { ESDs } & \text { Ecological Site Descriptions } \\ \text { ESI } & \text { Ecological Site Inventory } \\ \text { ESIS } & \text { Ecological Site Information System } \\ \text { EVT } & \text { Existing Vegetation Type } \\ \text { GAP } & \text { Gap Analysis Project } \\ \text { GPLCC } & \text { Great Plains Landscape Conservation Cooperative } \\ \text { LANDFIRE } & \text { Landscape Fire and Resource Management Planning Tools } \\ \text { NRCS } & \text { Natural Resources Conservation Service } \\ \text { REA } & \text { Rapid Ecoregional Assessment } \\ \text { SSURGO } & \text { Soil Survey Geographic Database } \\ \text { USGS } & \text { U.S. Geological Survey }\end{array}$

\section{Scientific Names for Species Mentioned in This Report}

$\begin{array}{ll}\text { Common Name } & \text { Scientific Name } \\ \text { Alkali cordgrass } & \text { Spartina gracilis } \\ \text { Alkali sacaton } & \text { Sporobolus airoides } \\ \text { Arizona cottontop } & \text { Digitaria californica } \\ \text { Arizona fescue } & \text { Festuca arizonica } \\ \text { Big bluestem } & \text { Andropogon gerardii } \\ \text { Black grama } & \text { Bouteloua eriopoda } \\ \text { Blue grama } & \text { Bouteloua gracilis } \\ \text { Bluebunch wheatgrass } & \text { Pseudoroegneria spicata spicata } \\ \text { Buffalograss } & \text { Bouteloua dactyloides } \\ \text { Cane bluestem } & \text { Bothriochloa barbinodis } \\ \text { Green needlegrass } & \text { Nassella viridula } \\ \text { Gypsum grama } & \text { Bouteloua breviseta } \\ \text { Idaho fescue } & \text { Festuca idahoensis } \\ \text { Indiangrass } & \text { Sorghastrum nutans } \\ \text { Inland saltgrass } & \text { Distichlis spicata } \\ \text { Little bluestem } & \text { Schizachyrium scoparium } \\ \text { Mountain brome } & \text { Bromus marginatus } \\ \text { Mountain muhly } & \text { Muhlenbergia montana } \\ \text { Needle and thread } & \text { Hesperostipa comata } \\ \text { Prairie sandreed } & \text { Calamovilfa longifolia } \\ \text { Sand bluestem } & \text { Andropogon hallii } \\ \text { Sand sagebrush } & \text { Aretemesia filifolia } \\ \text { Sand dropseed } & \text { Sporobolus cryptandrus } \\ \text { Shinnery oak } & \text { Quercus havardii } \\ \text { Sideoats grama } & \text { Bouteloua curtipendula } \\ \end{array}$




\section{Scientific Names for Species Mentioned in This Report-Continued}

\author{
Common Name \\ Silver beardgrass \\ Streambank wheatgrass \\ Switchgrass \\ Threadleaf sedge \\ Tobosagrass \\ Vine mesquite \\ Western wheatgrass
}

\author{
Scientific Name \\ Bothriochloa laguroides torreyana \\ Elymus lanceolatus lanceolatus \\ Panicum virgatum \\ Carex filifolia \\ Pleuraphis mutica \\ Panicum obtusum \\ Pascopyrum smithii
}

\section{Acknowledgments}

The impetus and oversight for this project were provided by the Southern Great Plains Rapid Ecoregional Assessment advisors and technical experts including Steve Tryon, David Wood, Melanie Barnes, Janine Book, and Laurence Levesque of the Bureau of Land Management, and Nicole Athearn of the Great Plains Landscape Conservation Cooperative. We greatly appreciate technical reviews of the general approach or the estimated historical grassland map provided by Robert Means and George Soehn of the Bureau of Land Management; Lee Elliot, Missouri Resource Assessment Partnership; Rick Schneider, Nebraska Natural Heritage Program; Esteban Muldavin, New Mexico Natural Heritage Program; Duane German, Texas Parks and Wildlife Department; Joe Stevens, Joanna Lemly, Karin Decker, and Michael Menefee, Colorado Natural Heritage Program; Patrick J. Comer, NatureServe; Steven Rolfsmeier, Chadron State College; Russell Martin, Texas Parks and Wildlife; Russ Horton, Oklahoma Department of Wildlife Conservation; and Kelly Kindscher, Kansas Biological Survey. Tammy Fancher, Patrick Anderson, and Colin Talbert of the U.S. Geological Survey provided reviews of this report, the data release, and the associated metadata. 


\title{
Estimated Historical Distribution of Grassland Communities of the Southern Great Plains
}

By Gordon C. Reese, ${ }^{1}$ Daniel J. Manier, ${ }^{1}$ Natasha B. Carr, ${ }^{1}$ Ramana Callan, ${ }^{2}$ Ian I. F. Leinwand, ${ }^{2}$

Timothy J. Assal, ${ }^{1}$ Lucy Burris, ${ }^{1}$ and Drew A. Ignizio ${ }^{1}$

\begin{abstract}
The purpose of this project was to map the estimated distribution of grassland communities of the Southern Great Plains prior to Euro-American settlement. The Southern Great Plains Rapid Ecoregional Assessment (REA), under the direction of the Bureau of Land Management and the Great Plains Landscape Conservation Cooperative, includes four ecoregions: the High Plains, Central Great Plains, Southwestern Tablelands, and the Nebraska Sand Hills. The REA advisors and stakeholders determined that the mapping accuracy of available national land-cover maps was insufficient in many areas to adequately address management questions for the REA. Based on the recommendation of the REA stakeholders, we estimated the potential historical distribution of 10 grassland communities within the Southern Great Plains project area using data on soils, climate, and vegetation from the Natural Resources Conservation Service (NRCS) including the Soil Survey Geographic Database (SSURGO) and Ecological Site Information System (ESIS). The dominant grassland communities of the Southern Great Plains addressed as conservation elements for the REA area are shortgrass, mixed-grass, and sand prairies. We also mapped tall-grass, mid-grass, northwest mixed-grass, and cool season bunchgrass prairies, saline and foothill grasslands, and semi-desert grassland and steppe. Grassland communities were primarily defined using the annual productivity of dominant species in the ESIS data. The historical grassland community classification was linked to the SSURGO data using vegetation types associated with the predominant component of mapped soil units as defined in the ESIS data. We augmented NRCS data with Landscape Fire and Resource Management Planning Tools (LANDFIRE) Biophysical Settings classifications 1) where NRCS data were unavailable and 2) where fifth-level watersheds intersected the boundary of the High Plains ecoregion in Wyoming. Spatial data representing the estimated historical distribution of grassland communities of the Southern Great Plains are provided as a $30 \times 30$-meter gridded surface (raster dataset). This information will help to address the priority management questions for grassland communities for the Southern Great Plains REA and can be used to inform other regional-level land management decisions.
\end{abstract}

\section{Purpose and Scope}

The Bureau of Land Management (BLM) is implementing a landscape approach that incorporates multiscale information to assess the condition and trends of resources (http://www.blm.gov/wo/st/en/prog/more/Landscape_Approach.html). A major component of the BLM

\footnotetext{
${ }^{1}$ U.S. Geological Survey.

${ }^{2}$ Cherokee Nation Technologies.
} 
landscape approach is the Rapid Ecoregional Assessment (REA) program, which provides information to facilitate development of broad-scale management strategies across jurisdictional boundaries. The REAs identify and map priority ecological communities and species for particular ecoregions, determine the degree of risk from development and other change agents, and provide assessments of ecological conditions including conservation and restoration potential. The purpose of this project was to map the estimated distribution of grassland communities of the Southern Great Plains prior to Euro-American settlement.

The BLM partnered with the Great Plains Landscape Conservation Cooperative (GPLCC) to ensure that the results of the Southern Great Plains REA provide information useful for addressing management issues identified by a diverse set of stakeholders representing the REA and GPLCC. The Southern Great Plains REA project area includes the full extent of the GPLCC's area (http://www.greatplainslcc.org/about/), as well as the following Omernik Level III ecoregions (Omernik, 1987): High Plains, Central Great Plains, Southwestern Tablelands, and the Nebraska Sand Hills (and an adjacent buffer delineated by fifth-level watersheds intersecting the ecoregion boundaries) (fig. $1 A$ ). The dominant vegetation communities in these four ecoregions are shortgrass, mixed-grass, and sand prairies, which were identified as priority ecological communities by the Southern Great Plains REA stakeholders (Assal and others, 2015). A priority management issue for this REA is how development (including agricultural, energy, transportation, and urban) has fragmented and reduced connectivity of Great Plains ecological communities (Assal and others, 2015). Our objective was to map the estimated distribution of grassland communities of the Southern Great Plains prior to EuroAmerican settlement to address management questions for the REA.

Both current and estimated historical land-cover maps were needed to quantify how development has altered landscape structure. For previous REAs, regional or national land-cover datasets, such as those from the Gap Analysis Program (GAP) and the Landscape Fire and Resource Management Planning Tools (LANDFIRE) program were used to map ecological communities (Bryce and others, 2012; Carr and Melcher, 2015; Comer and others, 2013). Because of the accuracy limitations of existing land-cover datasets and challenges associated with mapping the estimated distribution of grasslands prior to land-use conversions, REA stakeholders suggested using the Ecological Site Information System (ESIS) (National Resources Conservation Service, 2015a) and Soil Survey Geographic Database (SSURGO) (National Resources Conservation Service, 2015b) to map the estimated historical distribution of native grassland communities across the Southern Great Plains for the REA.

We conducted a preliminary review and analysis of the suitability of using existing land-cover datasets, including GAP (http://gapanalysis.usgs.gov/) and LANDFIRE (Landscape Fire and Resource Management Planning Tools, 2012), to map the priority grassland communities for the REA project area. The large size of the project area (spanning eight states) required two GAP regions (northwest and southwest); pronounced classification discrepancies along the boundaries precluded the use of the GAP data for mapping grasslands for the REA. We evaluated two LANDFIRE datasets for use: Biophysical Settings (BpS), representing the potential natural vegetation prior to Euro-American settlement, and Existing Vegetation Type (EVT) (Rollins, 2009).

LANDFIRE was developed to map fuels and typically depicts woody fuels more accurately than herbaceous fuels in rangelands because of limited field data in rangelands (Reeves and others, 2009). For comparison purposes, we used the Texas Ecological Systems Classification vegetation map, developed by the Missouri Resource Assessment Program (Elliot, 2010), as our reference map in the area of overlap between the Texas vegetation map and the REA project area because the finer resolution (10 x 10-meter raster dataset) and extensive field data (14,000 survey plots) were assumed to provide a 

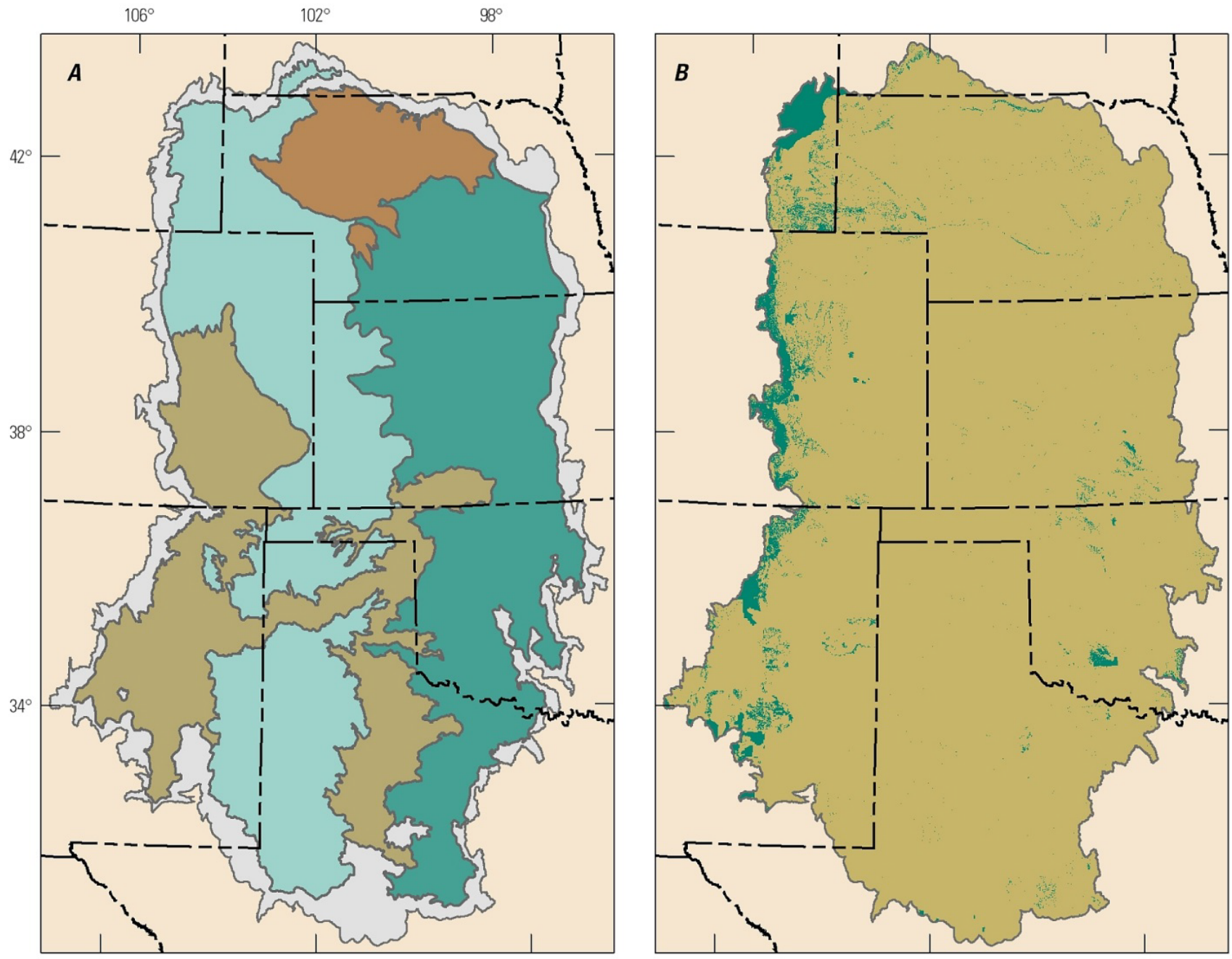

Base map is the intellectual property of Esri and is used herein under license. Copyright (C) 2014 Esri and its licensors. All rights reserved.

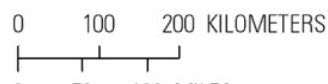

EXPLANATION

$0 \quad 50 \quad 100$ MILES

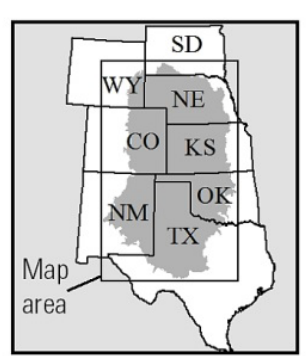

\section{Ecoregion}

Central Great Plains

High Plains

Nebraska Sand Hills

Southwestern Tablelands

Other

\section{EXPLANATION}

Data source

Natural Resources Conservation Service

LANDFIRE Biophysical Settings

Figure 1. Map of the Southern Great Plains Rapid Ecoregional Assessment project area. A, Omernik Level III ecoregions and the buffer region, which includes fifth-level watersheds intersected by the ecoregion boundaries and covers the full extent of the Great Plains Landscape Conservation Cooperative. B, Spatial coverage of the primary (National Resources Conservation Service) and supplemental (Landscape Fire and Resource Management Planning Tools) data sources used to estimate the historical distribution of grassland and other community types. 
more accurate map than LANDFIRE or NRCS data. Our preliminary analysis indicated that NRCSderived classifications, which combine information from both ESIS and SSURGO, generally had the best correspondence with the Texas Ecological Systems Classification, compared to LANDFIRE EVT and BpS, supporting the REA stakeholders' recommendation to use NRCS data to map grasslands for the Southern Great Plains REA. This approach assumes that the combination of substrate and climate is correlated with the composition and productivity of prairie vegetation. Understanding of these relations is in accord with common assumptions that underlie the development and use of Ecological Site Descriptions (ESDs) and is well established in practice and empirical research (for example, Epstein and others, 1998).

\section{Methods}

The potential distribution (Zerbe, 1998) of grass-dominated ecological communities in the Southern Great Plains was estimated using soil composition, annual precipitation, and vegetation plot data developed by the NRCS. SSURGO contains soil information delineated by map units and we used the dominant soils component, as represented by the largest percentage, for any map unit with multiple soil components to map the distribution of soil types.

Plant communities for each SSURGO map unit were identified using the ESIS (https://esis.sc.egov.usda.gov). Ecological sites are characterized by soil and physical characteristics, associated plant communities, vegetation productivity, and the potential for a given community to respond similarly to management actions and natural disturbances. The ESIS includes the Ecological Site Inventory (ESI) database and ESDs. The ESI provides plot-level survey data on soils and plant species productivity for each ecological site. The ESDs are peer reviewed reports that include summarized plot-level survey data and synthesize information on physical factors (soils, temperature, precipitation, hydrology, geology, physiographic features), biotic features (plant species occurrence, plant community composition, plant production), and ecological dynamics (disturbance regimes such as grazing, fire, drought). To associate each spatial map unit with the appropriate ecological site, the Soil Component and Ecoclass tables in SSURGO were used.

We classified the composition of sites for the project area into 10 grassland community types (shortgrass, mixed-grass, sand, tall-grass, mid-grass, northwest mixed-grass, and cool season bunchgrass prairies; semi-desert grassland and steppe; and saline and foothill grasslands; table 1). Our classification considered the naming conventions established by the National Vegetation Classification (Nelson and others, 2015) and used the same terminology when applicable. However, to support requests from managers and planners, we developed a classification falling between Group and Association levels of the National Vegetation Classification hierarchy similar to types considered in habitat conservation and management. Only shortgrass, mixed-grass, and sand prairies are widely distributed throughout the four ecoregions in the project area; the remaining seven grassland types primarily occur along the periphery of the ecoregions and in the buffer region. Although the less common grassland types were not a focus of our classification, they were included for completeness and context relative to adjacent areas.

To classify each ecological site, we used the three dominant species, as indicated by aboveground annual productivity (table 1). We followed species naming conventions established by the U.S. Department of Agriculture (Natural Resources Conservation Service, 2015c). Field estimates of species productivity from ESI vegetation plots within ecological sites without ESDs were averaged by species and normalized by calculating the percent of total annual yield in each ecological site. Ecological sites with mesic soils or wetland plants were classified as aquatic communities and sites dominated by woody species were classified as shrubland, woodland, and forest. LANDFIRE BpS 
(Landscape Fire and Resource Management Planning Tools, 2012) was used to classify areas with insufficient NRCS data and areas within the Southern Great Plains buffer region (fig. 1B), accounting for approximately 4 percent of the project area.

Table 1. Dominant indicator species used to classify ecological sites into grassland communities.

\begin{tabular}{ll}
\hline \multicolumn{1}{c}{ Community type } & \multicolumn{1}{c}{ Dominant indicator species } \\
\hline Shortgrass prairie & Blue grama, buffalograss, western wheatgrass \\
Mixed-grass prairie & Big bluestem, blue grama, little bluestem, sideoats grama \\
Sand prairie & Prairie sandreed, sand bluestem, sand dropseed, sand sagebrush, shinnery oak \\
Tall-grass prairie & Big bluestem, Indiangrass, little bluestem, switchgrass \\
Mid-grass prairie & Arizona cottontop, cane bluestem, sideoats grama, silver beardgrass, vine mesquite \\
Northwest mixed-grass prairie & Bluebunch wheatgrass, green needlegrass, Idaho fescue, streambank wheatgrass \\
Cool season bunchgrass prairie & Blue grama, needle and thread, threadleaf sedge, western wheatgrass \\
Semi-desert grassland and steppe & Black grama, gypsum grama, tobosagrass \\
Saline grassland & Alkali cordgrass, alkali sacaton, inland saltgrass \\
Foothill grassland & Arizona fescue, mountain brome, mountain muhly \\
\hline
\end{tabular}

Initial mapping of grassland communities using SSURGO and the associated ESIS revealed gaps and inconsistencies resulting from missing data and inaccurate classification boundaries along county and state lines. Map units lacking associated ESDs or ESI data were classified using vegetation described for nearby ecological sites with similar soil properties. Map units with classification inconsistencies along political boundaries (county or state lines) were assigned to the same community class as an adjacent ecological site with similar soil properties. In a small portion of the project area, nearby sites with similar soil properties were lacking; in these cases, we used LANDFIRE BpS to address the data gap (fig. $1 B$ ). The source of information used to classify map units is documented in the "Dataset source" attribute (table 2).

The estimated historical distribution map delineates 10 grassland communities (fig. 2). To provide a complete coverage of other communities in the project area, we also used NRCS and LANDFIRE BpS to map the estimated historical distribution of shrublands, woodlands, and forests; riparian areas and wetlands; open water; and sparsely vegetated land-cover classes. Because our purpose was to classify and map the historical distribution of grasslands, the woody and aquatic communities were grouped into general community types. To identify potential wetland and riparian areas, NRCS data were used to identify the presence of mesic soils and hydrophilic plant species; identification of potential shrublands, savanna, and open woodlands used the presence of indicator grasses and shrubs, and tree species (oak, juniper, or pine) with 10 to 25 percent cover. In areas where LANDFIRE BpS was used as the data source for classifying woody vegetation, we combined all vegetation types using the $\mathrm{BpS}$ names corresponding to shrublands, woodlands, and forests (table 3). We reclassified several BpS types corresponding to desert scrub types as saline grasslands because those scrub types are uncommon within the project area and generally occurred in proximity to areas classified as saline grasslands using NRCS data (table 3), supporting the reclassification.

The attribute names in the dataset are listed and defined in table 2 (Callan and others, 2016). The attributes include those derived by the U.S. Geological Survey (USGS) and attributes from the SSURGO data that were used in determining land-cover classification. The associated metadata includes expanded attribute definitions summarized in table 2 (Callan and others, 2016). 
Table 2. Attributes (names and abbreviations), definitions, and originator of the attribute field for the estimated historical distribution of grassland communities dataset. Attribute abbreviations are used in the dataset attribute table and defined in the metadata (Callan and others, 2016).

[NRCS, Natural Resources Conservation Service]

\begin{tabular}{|c|c|c|c|}
\hline $\begin{array}{l}\text { Attribute } \\
\text { originator }\end{array}$ & $\begin{array}{l}\text { Attribute } \\
\text { name }\end{array}$ & $\begin{array}{c}\text { Attribute } \\
\text { abbreviation }\end{array}$ & Definition \\
\hline \multirow{9}{*}{$\begin{array}{l}\text { U.S. Geological } \\
\text { Survey }\end{array}$} & Object Identifier & OID & Unique identifier for each row in the attribute table \\
\hline & Feature Value & Value & $\begin{array}{l}\text { Grid cells linked by a feature will have identical } \\
\text { values }\end{array}$ \\
\hline & Count & Count & Count of grid cells for the Feature Value \\
\hline & Vegetation Class & Class & Assigned vegetation community class \\
\hline & Vegetation Class Code & ClassCode & Numerical representation of the Vegetation Class \\
\hline & Dataset source & DataSource & $\begin{array}{l}\text { Source of the data used to identify and classify the } \\
\text { Vegetation Class }\end{array}$ \\
\hline & Type of information & Info_Type & $\begin{array}{l}\text { Type of information used to classify the Vegetation } \\
\text { Class }\end{array}$ \\
\hline & $\begin{array}{l}\text { Additional details on } \\
\text { data used }\end{array}$ & DataDetail & $\begin{array}{l}\text { Additional details on the data used to classify the } \\
\text { Vegetation Class }\end{array}$ \\
\hline & Lookup Key & LookupKey & $\begin{array}{l}\text { Ecological Site Description ID, map unit key, or } \\
\text { NRCS classification used to identify the } \\
\text { Vegetation Class; this is the spatial unit to which a } \\
\text { Vegetation Class is assigned }\end{array}$ \\
\hline \multirow{8}{*}{$\begin{array}{l}\text { Natural Resources } \\
\text { Conservation } \\
\text { Service }^{1}\end{array}$} & Map Unit Key & Mukey & $\begin{array}{l}\text { Map Unit Key is the unique identifier from the } \\
\text { NRCS soil component table }\end{array}$ \\
\hline & Component Key & Cokey & $\begin{array}{l}\text { Component Key is a string of characters used to } \\
\text { uniquely identify a record from the NRCS } \\
\text { component table }\end{array}$ \\
\hline & Component Percentage & Comppct_r & $\begin{array}{l}\text { Percentage of the soil component of the map unit } \\
\text { from the NRCS component table }\end{array}$ \\
\hline & Component Name & Compname & $\begin{array}{l}\text { Name assigned to a NRCS soil component based on } \\
\text { the soil properties }\end{array}$ \\
\hline & Geomorphic Description & Geomdesc & $\begin{array}{l}\text { A narrative description of the geomorphic setting of } \\
\text { the soil component }\end{array}$ \\
\hline & Taxonomic Class Name & Taxclname & $\begin{array}{l}\text { The taxonomic class from the NRCS component } \\
\text { table; the name is a concatenation of the soil } \\
\text { taxonomy subgroup and family for a given soil }\end{array}$ \\
\hline & $\begin{array}{l}\text { Ecological Classification } \\
\text { Identifier }\end{array}$ & Ecoclassid & $\begin{array}{l}\text { Identifier of a particular ecological community from } \\
\text { the NRCS coecoclass table }\end{array}$ \\
\hline & $\begin{array}{l}\text { Ecological Classification } \\
\text { Name }\end{array}$ & Ecoclassna & $\begin{array}{l}\text { Descriptive name of a particular ecological } \\
\text { community from the NRCS coecoclass table }\end{array}$ \\
\hline
\end{tabular}

\footnotetext{
${ }^{1}$ Soil Survey Geographic Database (SSURGO).
} 


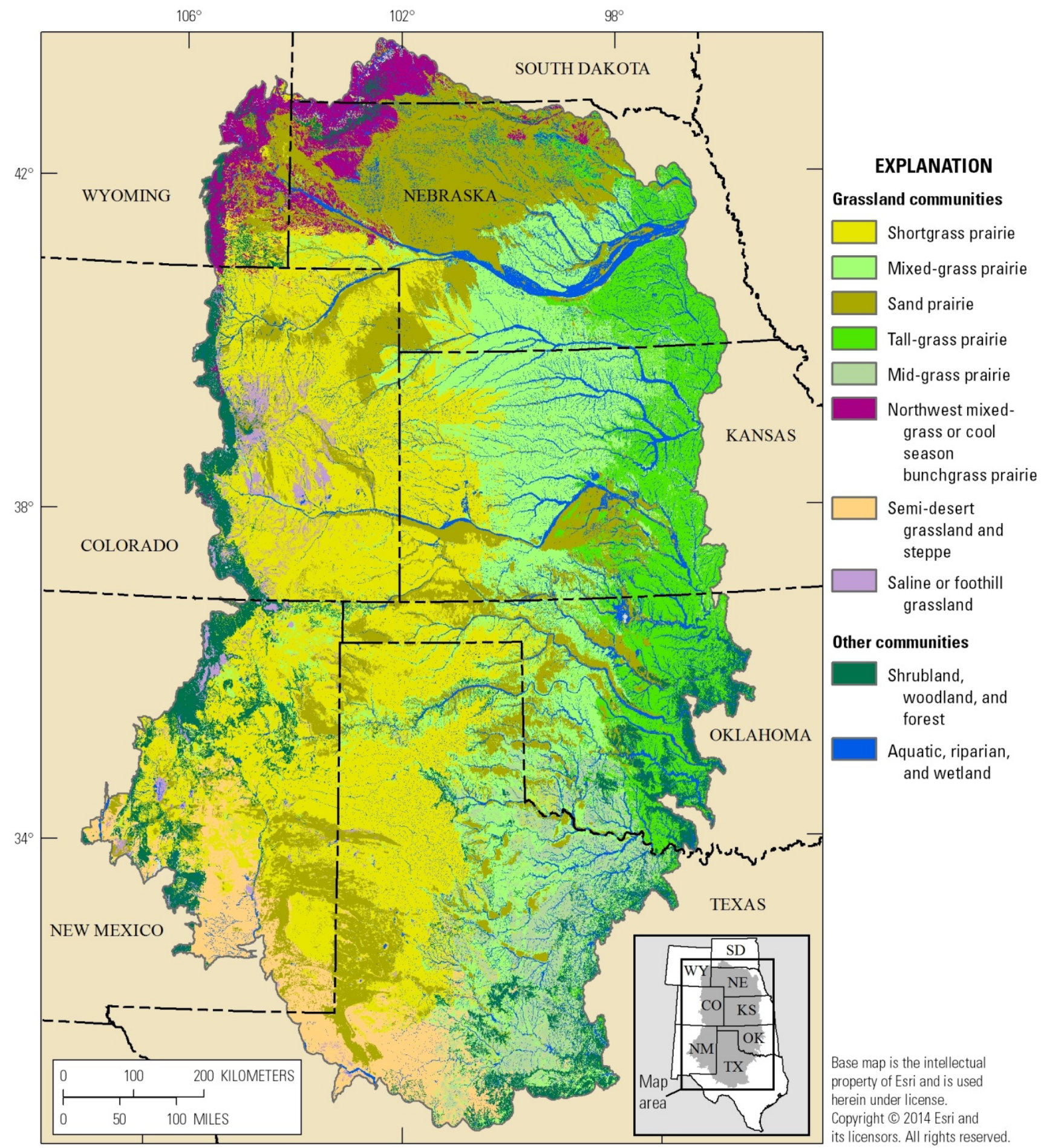

Figure 2. Map showing the estimated historical distribution of grassland and adjacent communities in the Southern Great Plains Rapid Ecoregional Assessment project area, which includes the Great Plains Landscape Conservation Cooperative area. For illustration, several minor grassland communities are combined and sparsely vegetated areas are not displayed due to their small size, but are retained in the dataset. 
Table 3. Community types for the estimated historical distribution of grasslands dataset and corresponding LANDFIRE Biophysical Settings names.

[LANDFIRE, Landscape Fire and Resource Management Planning Tools]

\begin{tabular}{|c|c|c|}
\hline Community type & Biophysical Settings name & $\begin{array}{l}\text { LANDFIRE } \\
\text { Code }\end{array}$ \\
\hline Cool season bunchgrass prairie $^{1}$ & Not applicable & \\
\hline \multirow[t]{5}{*}{ Foothill grassland } & Northern Rocky Mountain Lower Montane-Foothill-Valley Grassland & 11390 \\
\hline & Northern Rocky Mountain Subalpine-Upper Montane Grassland & 11400 \\
\hline & Rocky Mountain Subalpine-Montane Mesic Meadow & 11450 \\
\hline & Southern Rocky Mountain Montane-Subalpine Grassland & 11460 \\
\hline & Western Great Plains Foothill and Piedmont Grassland & 11470 \\
\hline Mixed-grass prairie & Central Mixedgrass Prairie & 11320 \\
\hline Northwest mixed-grass prairie & Northwestern Great Plains Mixedgrass Prairie & 11410 \\
\hline \multirow[t]{4}{*}{ Saline grassland ${ }^{2}$} & Chihuahuan Mixed Salt Desert Scrub & 10750 \\
\hline & Inter-Mountain Basins Mixed Salt Desert Scrub & 10810 \\
\hline & Inter-Mountain Basins Mixed Salt Desert Scrub—South & 10811 \\
\hline & Inter-Mountain Basins Mixed Salt Desert Scrub—North & 10812 \\
\hline \multirow[t]{4}{*}{ Sand prairie } & Chihuahuan Stabilized Coppice Dune and Sand Flat Scrub & 10760 \\
\hline & Western Great Plains Sandhill Steppe & 10940 \\
\hline & Western Great Plains Sand Prairie & 11480 \\
\hline & Chihuahuan Sandy Plains Semi-Desert Grassland & 11330 \\
\hline \multirow{5}{*}{$\begin{array}{l}\text { Semi-desert grassland and } \\
\text { steppe }\end{array}$} & Chihuahuan Grama Grass-Creosote Steppe & 11003 \\
\hline & Apacherian-Chihuahuan Semi-Desert Grassland and Steppe & 11210 \\
\hline & Chihuahuan Gypsophilous Grassland and Steppe & 11220 \\
\hline & Inter-Mountain Basins Semi-Desert Grassland & 11350 \\
\hline & Chihuahuan Loamy Plains Desert Grassland & 15030 \\
\hline Shortgrass Prairie & Western Great Plains Shortgrass Prairie & 11490 \\
\hline \multirow[t]{4}{*}{ Tall-grass Prairie } & Western Great Plains Tallgrass Prairie & 11500 \\
\hline & Central Tallgrass Prairie & 14210 \\
\hline & Southern Blackland Tallgrass Prairie & 14220 \\
\hline & Southeastern Great Plains Tallgrass Prairie & 14230 \\
\hline \multirow{9}{*}{$\begin{array}{l}\text { Shrubland, woodland, and } \\
\text { forest }\end{array}$} & Rocky Mountain Aspen Forest and Woodland & 10110 \\
\hline & Western Great Plains Dry Bur Oak Forest and Woodland & 10130 \\
\hline & Colorado Plateau Pinyon-Juniper Woodland & 10160 \\
\hline & Madrean Encinal & 10230 \\
\hline & Madrean Lower Montane Pine-Oak Forest and Woodland & 10240 \\
\hline & Madrean Pinyon-Juniper Woodland & 10250 \\
\hline & Northwestern Great Plains Highland White Spruce Woodland & 10480 \\
\hline & Rocky Mountain Foothill Limber Pine-Juniper Woodland & 10490 \\
\hline & Rocky Mountain Lodgepole Pine Forest & 10500 \\
\hline
\end{tabular}


Table 3. Community types for the estimated historical distribution of grasslands dataset and corresponding LANDFIRE Biophysical Settings names.-Continued

[LANDFIRE, Landscape Fire and Resource Management Planning Tools]

\begin{tabular}{|c|c|c|}
\hline Community type & Biophysical Settings name & $\begin{array}{l}\text { LANDFIRE } \\
\text { Code }\end{array}$ \\
\hline \multirow[t]{33}{*}{$\begin{array}{l}\text { Shrubland, woodland, and } \\
\text { forest-Continued }\end{array}$} & $\begin{array}{l}\text { Southern Rocky Mountain Dry-Mesic Montane Mixed Conifer Forest and } \\
\text { Woodland }\end{array}$ & 10510 \\
\hline & Southern Rocky Mountain Mesic Montane Mixed Conifer Forest and Woodland & 10520 \\
\hline & Southern Rocky Mountain Ponderosa Pine Woodland & 10540 \\
\hline & Southern Rocky Mountain Ponderosa Pine Woodland-South & 10541 \\
\hline & Southern Rocky Mountain Ponderosa Pine Woodland-North & 10542 \\
\hline & Rocky Mountain Subalpine Dry-Mesic Spruce-Fir Forest and Woodland & 10550 \\
\hline & Rocky Mountain Subalpine Mesic-Wet Spruce-Fir Forest and Woodland & 10560 \\
\hline & Rocky Mountain Subalpine-Montane Limber-Bristlecone Pine Woodland & 10570 \\
\hline & Southern Rocky Mountain Pinyon-Juniper Woodland & 10590 \\
\hline & Inter-Mountain Basins Aspen-Mixed Conifer Forest and Woodland & 10610 \\
\hline & $\begin{array}{l}\text { Inter-Mountain Basins Aspen-Mixed Conifer Forest and Woodland-Low } \\
\text { Elevation }\end{array}$ & 10611 \\
\hline & Inter-Mountain Basins Curl-leaf Mountain Mahogany Woodland and Shrubland & 10620 \\
\hline & Colorado Plateau Mixed Low Sagebrush Shrubland & 10640 \\
\hline & Inter-Mountain Basins Mat Saltbush Shrubland & 10660 \\
\hline & Rocky Mountain Alpine Dwarf-Shrubland & 10700 \\
\hline & Wyoming Basins Dwarf Sagebrush Shrubland and Steppe & 10720 \\
\hline & Chihuahuan Creosotebush Desert Scrub & 10740 \\
\hline & Chihuahuan Succulent Desert Scrub & 10770 \\
\hline & Inter-Mountain Basins Big Sagebrush Shrubland & 10800 \\
\hline & Inter-Mountain Basins Big Sagebrush Shrubland—Basin Big Sagebrush & 10801 \\
\hline & Inter-Mountain Basins Big Sagebrush Shrubland—Wyoming Big Sagebrush & 10802 \\
\hline & Mojave Mid-Elevation Mixed Desert Scrub & 10820 \\
\hline & Northwestern Great Plains Shrubland & 10850 \\
\hline & Rocky Mountain Lower Montane-Foothill Shrubland & 10860 \\
\hline & $\begin{array}{l}\text { Rocky Mountain Lower Montane-Foothill Shrubland-No True Mountain } \\
\text { Mahogany }\end{array}$ & 10861 \\
\hline & $\begin{array}{l}\text { Rocky Mountain Lower Montane-Foothill Shrubland-True Mountain } \\
\text { Mahogany }\end{array}$ & 10862 \\
\hline & Southern Colorado Plateau Sand Shrubland & 10930 \\
\hline & Apacherian-Chihuahuan Mesquite Upland Scrub & 10950 \\
\hline & Chihuahuan Mixed Desert and Thorn Scrub & 11000 \\
\hline & Chihuahuan Mixed Desert Shrubland & 11002 \\
\hline & Madrean Oriental Chaparral & 11010 \\
\hline & Colorado Plateau Pinyon-Juniper Shrubland & 11020 \\
\hline & Mogollon Chaparral & 11040 \\
\hline
\end{tabular}


Table 3. Community types for the estimated historical distribution of grasslands dataset and corresponding LANDFIRE Biophysical Settings names.-Continued

[LANDFIRE, Landscape Fire and Resource Management Planning Tools]

\begin{tabular}{|c|c|c|}
\hline Community type & Biophysical Settings name & $\begin{array}{l}\text { LANDFIRE } \\
\text { Code }\end{array}$ \\
\hline \multirow{24}{*}{$\begin{array}{l}\text { Shrubland, woodland, and } \\
\text { forest_Continued }\end{array}$} & Rocky Mountain Gambel Oak-Mixed Montane Shrubland & 11070 \\
\hline & Sonora-Mojave Semi-Desert Chaparral & 11080 \\
\hline & Western Great Plains Mesquite Woodland and Shrubland & 11110 \\
\hline & Inter-Mountain Basins Juniper Savanna & 11150 \\
\hline & Madrean Juniper Savanna & 11160 \\
\hline & Southern Rocky Mountain Ponderosa Pine Savanna & 11170 \\
\hline & Southern Rocky Mountain Ponderosa Pine Savanna-South & 11171 \\
\hline & Southern Rocky Mountain Ponderosa Pine Savanna-North & 11172 \\
\hline & Southern Rocky Mountain Juniper Woodland and Savanna & 11190 \\
\hline & Inter-Mountain Basins Big Sagebrush Steppe & 11250 \\
\hline & Inter-Mountain Basins Montane Sagebrush Steppe & 11260 \\
\hline & Inter-Mountain Basins Semi-Desert Shrub-Steppe & 11270 \\
\hline & Inter-Mountain Basins Greasewood Flat & 11530 \\
\hline & Middle Rocky Mountain Montane Douglas-fir Forest and Woodland & 11660 \\
\hline & Northwestern Great Plains-Black Hills Ponderosa Pine Woodland and Savanna & 11790 \\
\hline & $\begin{array}{l}\text { Northwestern Great Plains-Black Hills Ponderosa Pine Woodland and } \\
\text { Savanna-Low Elevation Woodland }\end{array}$ & 11791 \\
\hline & $\begin{array}{l}\text { Northwestern Great Plains-Black Hills Ponderosa Pine Woodland and } \\
\text { Savanna-Savanna }\end{array}$ & 11792 \\
\hline & Crosstimbers Oak Forest and Woodland & 13080 \\
\hline & North-Central Interior Dry-Mesic Oak Forest and Woodland & 13100 \\
\hline & North-Central Interior Maple-Basswood Forest & 13140 \\
\hline & Edwards Plateau Limestone Savanna and Woodland & 13830 \\
\hline & Tamaulipan Calcareous Thornscrub & 13920 \\
\hline & Edwards Plateau Limestone Shrubland & 13930 \\
\hline & Edwards Plateau Dry-Mesic Slope Forest and Woodland & 15230 \\
\hline Aquatic & Open Water & 11 \\
\hline \multirow[t]{8}{*}{ Riparian and wetlands } & Rocky Mountain Bigtooth Maple Ravine Woodland & 10120 \\
\hline & North American Warm Desert Riparian Systems & 11550 \\
\hline & Rocky Mountain Montane Riparian Systems & 11590 \\
\hline & Rocky Mountain Subalpine/Upper Montane Riparian Systems & 11600 \\
\hline & Western Great Plains Floodplain Systems & 11620 \\
\hline & Northwestern Great Plains Canyon & 13410 \\
\hline & Western Great Plains Wooded Draw and Ravine & 13850 \\
\hline & Eastern Great Plains Floodplain Systems & 14690 \\
\hline
\end{tabular}


Table 3. Community types for the estimated historical distribution of grasslands dataset and corresponding LANDFIRE Biophysical Settings names.-Continued

[LANDFIRE, Landscape Fire and Resource Management Planning Tools]

\begin{tabular}{llr}
\hline \multicolumn{1}{c}{ Community type } & \multicolumn{1}{c}{ Biophysical Settings name } & $\begin{array}{c}\text { LANDFIRE } \\
\text { Code }\end{array}$ \\
\hline $\begin{array}{c}\text { Riparian and wetlands- } \\
\text { Continued }\end{array}$ & Central Interior and Appalachian Floodplain Systems & 14710 \\
& Central Interior and Appalachian Riparian Systems & 14720 \\
& Eastern Great Plains Wet Meadow-Prairie-Marsh & 14880 \\
& Western Great Plains Depressional Wetland Systems & 14950 \\
& Western Great Plains Depressional Wetland Systems-Playa & 14951 \\
& Western Great Plains Depressional Wetland Systems-Saline & 14952 \\
& Chihuahuan-Sonoran Desert Bottomland and Swale Grassland & 15040 \\
& Chihuahuan-Sonoran Desert Bottomland and Swale Grassland-Tobosa & 15041 \\
& Grassland & 15042 \\
& Chihuahuan-Sonoran Desert Bottomland and Swale Grassland-Alkali Sacaton & 15250 \\
& Edwards Plateau Riparian & 12 \\
Perennial Ice/Snow & 31 \\
Barren-Rock/Sand/Clay & 10010 \\
& Inter-Mountain Basins Sparsely Vegetated Systems & 10040 \\
& North American Warm Desert Sparsely Vegetated Systems & 10060 \\
& Rocky Mountain Alpine/Montane Sparsely Vegetated Systems & 10070 \\
& Western Great Plains Sparsely Vegetated Systems & 11430 \\
Rocky Mountain Alpine Fell-Field & 11440 \\
Rocky Mountain Alpine Turf &
\end{tabular}

${ }^{1}$ Cool season bunchgrass prairie was not classified as a result of the use of LANDFIRE data.

${ }^{2}$ Several desert scrub types were reclassified as saline grasslands using data from the National Resources Conservation Service.

\section{Products}

Datasets associated with this report include a raster dataset in Tag Image File Format (.tif) representing the estimated historical distribution of grassland communities of the Southern Great Plains, the associated Federal Geographic Data Committee metadata in XML format, and a layer file (.lyr) used for cartographic display of the raster data (Callan and others, 2016).

\section{Disclaimers}

Any use of trade, firm, or product names is for descriptive purposes only and does not imply endorsement by the U.S. Government. Although these data have been processed successfully on a computer system at the USGS, no warranty expressed or implied is made regarding the display or utility of the data on any other system, or for general or scientific purposes, nor shall the act of distribution constitute any such warranty. The USGS shall not be held liable for improper or incorrect use of the data described and (or) contained herein. Maps provided within this document are not for navigational use. 


\section{Summary}

This project mapped the estimated historical distribution of grassland communities of the Southern Great Plains Rapid Ecoregional Assessment (REA) project area prior to Euro-American settlement. We mapped the distribution of 10 grassland communities within the project area including shortgrass, mixed-grass, and sand prairies which are the dominant grassland communities evaluated for the REA. Community types were primarily classified using the plant species with the largest annual productivity as identified by the Natural Resources Conservation Service (NRCS). We also used Landscape Fire and Resource Management Planning Tools (LANDFIRE) classifications where NRCS data were unavailable and in peripheral watersheds intersecting an ecoregion boundary. Some ecological sites were classified from only a few vegetation plots; consequently, the estimated historical distribution of grasslands is best suited to regional- and landscape-level applications as a result of these and other data limitations inherent in estimating the historical distribution of grasslands. The $30 \times 30-$ meter raster dataset of the estimated historical distribution of grassland communities (Callan and others, 2016) can be used to address management questions for the Southern Great Plains REA, Great Plains Landscape Conservation Cooperative, and other broad-scale management issues.

\section{References Cited}

Assal, T.J., Melcher, C.P., and Carr, N.B., eds., 2015, Southern Great Plains Rapid Ecoregional Assessment—Pre-assessment report: U.S. Geological Survey Open-File Report 2015-1003, 282 p., accessed June 23, 2016, at http://dx.doi.org/10.3133/ofr20151003.

Bryce, S.A., Strittholt, J.R. Ward, B.C., and Bachelet, D.M., 2012, Colorado Plateau Rapid Ecoregional Assessment Report: Denver, Colo., Prepared for the U.S. Department of the Interior, Bureau of Land Management, $158 \mathrm{p}$.

Callan, Ramana, Leinwand, I.I.F., Reese, G.C., Assal, T.J., Manier, D.J., Carr, N.B., Burris, Lucy, Ignizio, D.A., 2016, Estimated historical distribution of grassland communities of the Southern Great Plains: U.S. Geological Survey data release, https://dx.doi.org/10.5066/F71Z42J3.

Carr, N.B., and Melcher, C.P., eds., 2015, Wyoming Basin Rapid Ecoregional Assessment: U.S. Geological Survey Open-File Report 2015-1155, 896 p., accessed June 23, 2016, at http://dx.doi.org/10.3133/ofr20151155.

Comer, P., Crist, P., Reid, M., Hak, J., Hamilton, H., Braun, D., Kittel, G., Varley, I., Unnasch, B., Auer, S., Creutzburg, M., Theobald, D., and Kutner, L., 2013, Central Basin and Range Rapid Ecoregional Assessment report: Denver, Colo., Prepared for the U.S. Department of the Interior, Bureau of Land Management, 168 p., accessed June 23, 2016, at http://www.blm.gov/wo/st/en/prog/more/Landscape_Approach/reas/cbasinrange.html.

Elliot, L., 2010, Draft descriptions of systems, mapping subsystems, and vegetation types for Phase III: Columbia, Missouri, Missouri Resource Assessment Partnership, 86 p., accessed June 23, 2016, at http://www.cerc.usgs.gov/morap/Assets/UploadedFiles/Projects/Texas_Ecological_Systems_Classific ation/Phase_3_Systems_Descriptions.pdf.

Epstein, H.E., Lauenroth, W.K., Burke, I.C., and Coffin, D.P., 1998, Regional productivities of plant species in the Great Plains of the United States: Plant Ecology, v.134, p.173-195.

Landscape Fire and Resource Management Planning Tools, 2012, Biophysical Settings, LANDFIRE 1.3.0: U.S. Department of Agriculture, Forest Service, and U.S. Department of the Interior, Geological Survey, accessed May 6, 2015, at http://www.landfire.gov/NationalProductDescriptions20.php. 
Natural Resources Conservation Service, 2015a, Ecological Site Inventory System: Natural Resources Conservation Service, accessed July 2015 at https://esis.sc.egov.usda.gov.

Natural Resources Conservation Service, 2015b, Soil Survey Geographic Database, Natural Resources Conservation Service, accessed July 2015 at http://websoilsurvey.nrcs.usda.gov/.

Natural Resources Conservation Service, 2015c, The PLANTS database: Baton Rouge, La., National Plant Data Center, accessed July 2015 at http://plants.usda.gov.

Nelson, M.L., Brewer, K., and Solem, S.J., 2015, Existing vegetation classification, mapping and inventory technical guide version 2.0: Washington, D.C., U.S. Department of Agriculture, Forest Service General Technical Report WO-90, 212 p.

Omernik, J.M., 1987, Ecoregions of the conterminous United States [map supplement]: Annals of the Association of American Geographers, v. 77, no. 1, p. 118-125.

Reeves, M.C., Ryan, K.C., Rollins, M.G., and Thompson, T.G., 2009, Spatial fuel data products of the LANDFIRE project: International Journal of Wildland Fire, v. 18, p. 250-267.

Rollins, M.G., 2009, LANDFIRE-A nationally consistent vegetation, wildland fire, and fuel assessment: International Journal of Wildland Fire, v. 18, no. 3, p. 235-249.

Zerbe, S., 1998, Potential natural vegetation-Validity and applicability in landscape planning and nature conservation: Applied Vegetation Science, v. 1, no. 2, p. 165-172. 